управлять ими, вести единый реестр волонтерских объединений, обеспечивать стабильность занятости волонтеров.

Организационные коммуникации становятся неотъемлемым элементом жизнедеятельности вуза, позволяя ему быть открытым для общественности, реагировать на общественные изменения, вести диалог со своими целевыми аудиториями и оставаться в центре внимания [5]. Волонтерская организация как подразделение вуза принимает на себя функции ретранслятора культуры социально ответственного поведения, проводника социализации для молодых поколений. Успешная реализация миссии требует управления каналами и технологиями, позволяющими добровольческому движению артикулировать аудиториям свои идеи и программы, обмениваться информацией, рекрутировать участников. На данный момент диагностируется осознанный подход волонтерских организаций к коммуникациям как стратегически важному ресурсу. Конкуренция переходит от выбора каналов коммуникации к выбору стратегий эффективного донесения информации, что обуславливает актуальность будущих исследований механизмов управления новыми коммуникационными практиками в некоммерческом секторе.

\title{
Литература
}

1. Горьканова, Л.В. Организационное поведение : учеб. пособие / Р.М.Прытков, Л.В. Горьканова. - Оренбург : ГОУ ОГУ, 2011.

2. Коммуникационный менеджмент в вопросах и ответах (подготовка к экзамену): учебное пособие для вузов / И. В. Марусева. - М.; Берлин : ДиректМедиа, 2014. - С. 110.

3. Петрова А.А. Проблемы и пути развития молодежного волонтерского движения // Научное сообщество студентов XXI столетия. Гуманитарные науки: сб. ст. по мат. XLVI междунар. студ. науч.-практ. конф. № 9(46). URL: https://sibac.info/archive/guman/9(46).pdf (дата обращения: 11.04.2017)

4. Рева В.Е. Коммуникационный менеджмент: Учебно-методическое пособие. Пенза. Изд. ПГУ. 2003.

Рыжков О.В. Анализ коммуникационной стратегии МГУ им. М.В. Ломоносова // Материалы Международного молодежного научного форума «ЛОМОНОСОВ-2016». — М.: МАКС Пресс, 2016.

\section{ВОЗМОЖНОСТИ КИНОДИСКУРСА В ФОРМИРОВАНИИ НОВЫХ ПРЕДСТАВЛЕНИЙ}

Кубрак Т.А.

Глобализация информационного пространства, расширение возможностей средств массовой коммуникации остро ставят проблему психологического воздействия массмедийного дискурса [3].

Особую значимость эти вопросы приобретают при исследовании такого мощного средства массовой коммуникации как кино. Как и любой другой дискурс, кинодискурс отражает существующие ценности, представления, оценки и в то же время он их формирует, влияя на социальные процессы, происходящие в обществе. 
Сегодня кино является не только мощным средством массовой коммуникации, но и одним из самых распространенных видов досуга. Рост посещаемости кинотеатров, стремительно возрастающий интерес к просмотру сериалов показывают важную роль, которую играет кино в современном обществе. Возникают вопросы: какие представления о реальности создают современные фильмы, какие транслируют образы и формируют установки. Ставится и проблема информационно-психологической безопасности в кинодискурсе и противодействия ее угрозам [1].

При изучении вопросов воздействия большинство работ посвящено проблемам негативного влияния. Однако потенциал кино в плане позитивного воздействия изучается и используется еще недостаточно: фильмы могут задавать новые модели поведения, формировать установки и ценности.

Например, одной из актуальных проблем современного общества является охрана окружающей среды. В связи с этим возникает новый жанр в кино климатическая фантастика (Cli-fi), которая наглядно показывает, что нас ждет в ближайшем будущем, и предлагает задуматься, что мы можем сделать для избегания самых мрачных прогнозов. «Такие фильмы как голливудский «Послезавтра» (The Day After Tomorrow, 2004) или документальный «Неудобная правда» (An Inconvenient Truth, 2006) не просто рассказывают о проблеме и показывают, что будет, если ее не решить. Они пытаются вдохновлять на действие» (KINOTE. Как экологические фильмы могут помочь спасти мир? http://kinote.info/articles/13620-kak-ekologicheskie-filmy-mogutpomoch-spasti-mir). Так, после фильма-катастрофы «Послезавтра» выяснилось, что в разных точках мира зрители, посмотревшие этот фильм, были не только более обеспокоены изменением климата, но и хотели действовать: купить более энергоэкономную машину, пожертвовать деньги экологическим компаниям, влиять в своей стране на политику по эковопросам.

Фильмы могут менять ранее сформированные нормы и ценности: изучение телефильмов 80-90 х. гг. выявило наличие стереотипов в изображении пожилых людей [6] и инвалидов как социальных аутсайдеров, однако адекватное отображение факторов предубеждений вызвало рост толерантности к ним в обществе; фильмы о СПИДе способствовали более сострадательному отношению к ВИЧ-инфицированным; просмотр сериалов с позитивной подачей донорства помогал принимать решение о собственном донорстве [5, 7].

К сожалению, на сегодняшний день российские зрители серьезному кино о реальных проблемах предпочитают фэнтези, фантастику и анимацию; зачастую остаются без внимания фильмы, осмысляющие действительность, рассказывающие драматические истории человеческих жизней. Тем не менее, есть данные, что даже развлекательное кино, являющееся средством получения эмоциональной разрядки и отдыха, может заставить задуматься и даже изменить взгляды и установки [2].

\section{Экспериментальное исследование}

В настоящее время нами начато экспериментальное исследование воздействия кино на представления зрителей. 
В процессе разработки дизайна исследования уточнялся конкретный предмет исследования (изучаемые представления). Выбор определялся, с одной стороны, актуальностью темы, но при этом нахождении ее вне фокуса массмедиа, чтобы исключить влияние других медиа источников, с другой стороны, наличием соответствующего выбранной тематики фильма. В процессе дискуссии обсуждались, например, такие темы как донорство органов, наука, патриотизм и пр. Некоторые были исключены по причине отсутствия соответствующих фильмов. Например, исследование изменений представлений об отдельных профессиях затруднено в связи с отсутствием современных фильмов, популяризирующих их. И, наоборот, существуют фильмы, героями которых являются люди с ограниченными возможностями, но эта тема в настоящее время активно обсуждается в СМИ, в связи с чем нельзя исключить влияние на изменение представлений о них проводящейся общественной дискуссии. Кроме того, фильм должен был быть достаточно интерес и понятен. Учитывая все ограничения и возможности для реализации целей эксперимента, предметом исследования были выбраны представления о пожилых людях, а фильмом для показа - «Отель «Мэриголд»: Лучший из экзотических» (Великобритания, США, ОАЭ).

Для решения исследовательских задач использовалась психосемантическая методика для выявления содержания представлений о пожилых людях (25 оценочных шкал) [4]. Респонденты должны были оценить по 7-балльной шкале выраженность той или иной характеристики, относящейся к пожилым людям.

В настоящее время проведено пилотажное исследование, в котором приняло участие 11 человек в возрасте 18-23 лет. Респонденты в три этапа участвовали в опросе: перед просмотром фильма, сразу и через 2 недели после просмотра.

Были получены предварительные данные об эффективности воздействия кино на представления о пожилых людях. Оказалось, что по некоторым шкалам, например, таким, как «активная жизненная позиция - плывет по течению» или «новое не воспринимает - современный взгляд на новые вещи» произошли изменения содержания представлений сразу после просмотра фильма в сторону оценки пожилых людей, как более активных, открытых к новому опыту. Однако по прошествии двух недель не все изменения сохранились.

Результаты пилотажного исследования будут использованы в дальнейшей работе по исследованию воздействия кино на представления зрителей.

\section{Заключение}

Значимость исследований кино определяется возможностями его позитивного воздействия: формированием норм и ценностей, мнений и установок.

Экспериментальное исследование эффективности психологического воздействия позволяет получить как новые данные о механизмах воздействия кино, так и выявить потенциал кинодискурса в решении актуальных вопросов современного общества. 


\section{Литература}

1. Кубрак Т.А. Проблема информационно-психологической безопасности в кинодискурсе // Психологические исследования. 2016. T. 9, № 47. С. 8. URL: http://psystudy.ru (дата обращения: 15.04.2017).

2. Кубрак Т.А. Роль психологических характеристик восприятия кино в процессе его воздействия // Психологическое воздействие в межличностной и массовой коммуникации / Отв. ред. А.Л. Журавлева, Н.Д. Павловой. М.: Изд-во «Институт психологии РАН», 2014. С. 94-111.

3. Латынов В.В. Психология коммуникативного воздействия. М.: Институт психологии РАН, 2013.

4. Лемиш В.В. Представления студентов, обучающихся по специальности «социальная работа», о пожилых и старых людях // Известия Российского государственного педагогического университета им. А.И. Герцена. 2013. № 158. С. 36-48.

5. Харрис Р. Психология массовых коммуникаций. СПб.: Прайм Еврознак, 2002.

6. Harwood J., Giles H. 'Don't make me laugh': Age representations in a humorous context. Discourse and Society, 1992, 3, 403-436.

7. Morgan S.E., Movius L., Cody M.J. The power of nattatives: The effects of entertainment television organ donation storylines on the attitudes, knowledge, and behaviors of donors and nondonors. Journal of Communication, 2009, 59(1), 135151.

\section{СОВРЕМЕННЫЕ ПРОБЛЕМЫ ГЕНДЕРНОЙ ИДЕНТИЧНОСТИ Летюкова О.В., Школьная О.А.}

Понятие «идентичность» впервые детально было представлено Э. Эриксоном (E. Erikson), с точки зрения которого, идентичность опирается на осознание временной протяженности собственного существования, предполагает восприятие собственной целостности, позволяет человеку определять степень своего сходства с разными людьми при одновременном видении своей уникальности и неповторимости.

В связи с тем что общество сейчас представляет собой - систему глобальных трансформационных процессов и таких же глобальных общечеловеческих проблем: топливно-энергитической, демографической, социокультурной, антропологической и пр., среди этих важных проблемных направлений отдельно выделяется тема изменений гендерной культуры, а так же ослабление жесткой поляризации женских и мужских ролей в обществе.

Сегодня активно менятся психосексуальные роли и гендерные стереотипы. Модель женского поведения (ценности семьи, любви, детей, брака, преданности, послушания), которая была традиционной вытесняется инициативной моделью поведения, ценностями индивидуального успеха самореализация, свобода, профессия, секс, деньги, карьера. Женщины стали занимать более активную позицию и в семье, и в обществе. Всё чаще женщина 